\title{
The Advocate's Own Challenges to Behave in a Sustainable Way: An Institutional Analysis of Advocacy NGOs
}

\author{
Mieneke Koster $^{1} \cdot$ Ana Simaens $^{2} \cdot{\text { Bart } \operatorname{Vos}^{1}}^{1}$
}

Received: 31 December 2015/Accepted: 15 August 2017/Published online: 1 September 2017

(C) The Author(s) 2017. This article is an open access publication

\begin{abstract}
Non-governmental organizations (NGOs) are increasingly important drivers for businesses' self-regulation to operate in a sustainable way. We shift the perspective on NGOs from focusing on their advocacy role to focusing on their accountability for having sustainable internal operations. In a multiple case analysis, we explore the question 'What are the drivers and barriers to sustainable conduct of NGOs that are sustainability advocates?' Drawing on institutional theory, we obtain novel insights into the legitimacy-seeking motivations for sustainable conduct in the specific context of advocacy NGOs. We found that, affected by its mission, (1) the cultural-cognitive drive is particularly high, with sustainable conduct as an internally 'taken-forgranted' behavior, followed by (2) the normative drivers, with the balance between perceived vulnerability of needing to 'walk the talk' and the sense of immunity due to lack of external scrutiny, and (3) there are hardly any regulative drivers. Furthermore, these organizations face idiosyncratic trade-offs when balancing investments in their advocacy missions with investments in sustainable operations, reflecting ethical dilemmas. In a broader sense, this research elucidates the way advocates cope in situations of
\end{abstract}

Mieneke Koster

h.r.koster@uvt.nl

Ana Simaens

ana.simaens@iscte-iul.pt

Bart Vos

b.vos@uvt.nl

1 Tilburg University, Postbus 90153, 5000 LE Tilburg, Netherlands

2 Instituto Universitário de Lisboa (ISCTE-IUL), Business Research Unit (BRU-IUL), Av. das Forças Armadas, 1649-026 Lisbon, Portugal institutional complexity, with conflicting institutional demands between their mission and role-model function.

Keywords Institutional complexity · Legitimacy ·

Multiple cases · Non-governmental organizations (NGOs) · Sustainability

\section{Introduction}

'Well, we can't really imagine why you would (...) spend about like 50 to 100 thousand on doing all the certification work because the public assumes that you are clean and that you are complying.' This quote from the empirical study presented in this paper reflects the remarkable advice given by an audit firm to an environmental non-governmental organization (NGO), stating that an environmental certification would not be worthwhile in their situation. Contrary to firms that are often questioned about their sustainable conduct, this quote anecdotally demonstrates the public's assumption that advocacy NGOs 'walk their talk,' even though supporting evidence about the NGO's conduct is lacking. This points to an intriguing and somewhat delicate subject of whether and how NGOs acting as sustainability advocates are driven to embed sustainability in their own internal operations. This subject is of particular interest since it is widely accepted that NGOs are among the main drivers leading firms to selfregulate and adopt a sustainable approach in their operations (e.g., Campbell 2007; Waddock 2008). However, the study of drivers and barriers of sustainable conduct has focused more on firms (e.g., Bansal 2005; Bansal and Roth 2000; Delgado-Ceballos et al. 2012) than on NGOs.

This study addresses NGOs in the context of sustainability. NGOs are 'private, not-for-profit organizations that 
aim to serve particular societal interests by focusing advocacy and/or operational efforts on social, environmental, political and economic goals' (cf. Teegen et al. 2004) rather than profit maximization. In this paper, we focus on a specific type of NGOs that parallels to campaigning organizations (Handy 1990), which we refer to as NGOs acting as sustainability advocates. The number of NGOs-and their influence-has grown significantly; therefore, NGOs have been recognized as influential key actors in an international business context (Kourula and Laasonen 2010; Teegen et al. 2004; Waddock 2008).

The role of NGOs as watchdogs of large multinational corporations and their advocacy role in developing good practices are well established in the literature (e.g., Domeisen and Hulm 2006; Haack et al. 2012; Kong et al. 2002; Valente 2012; Van Cranenburgh et al. 2013).

However, when we shift the focus from NGOs as sustainability advocates to NGOs as responsible players themselves, it appears that information on NGOs' internal policies and practices is incomplete, or even absent in some cases (Simaens and Koster 2013), and in the literature there is a lack of attention dedicated to NGOs' internal sustainable practices [apart from initial research on NGOs' sustainability reporting (Simaens and Koster 2013), accountability and communicative action (Dhanani and Connolly 2015), and limited evidence of sustainable practices by NGOs (e.g., Low and Davenport 2009; Wiser et al. 2001)].

It is of interest to understand NGOs' responsibilities like sustainable internal conduct (cf. Kourula and Laasonen 2010), and here lies the novelty of the paper, as the role played by these advocates in terms of sustainability differs from that played by firms and even other types of NGOs, because sustainability is at the core of their mission. They face potential scrutiny regarding whether they 'walk the talk' internally; that is, practicing what they tell others to do while being advocates for a more sustainable world. As Fassin $(2009$, p. 503) notes when focusing on the ethical evaluation of actions undertaken by NGO's toward 'victim' corporations, the way 'NGOs themselves act does not always live up to the principles they advocate.' Hence, advocacy NGOs face specific institutional influences and have idiosyncrasies worth studying. Research with a focus on the position and drive of international NGOs, and especially the NGOs acting as sustainability advocates, can reveal novel insights into the influences that in a broader sense encourage other advocacy or advisory organizations to 'walk their talk'. We address the following research question: What are the drivers and barriers to sustainable conduct of NGOs that are sustainability advocates?

Sustainable conduct includes the triple-bottom-line perspective (Elkington 1998) via the integration of people, planet, and profit criteria into the culture, strategy, and operations of organizations (cf. Kleindorfer et al. 2005).
For the purpose of this paper, we focus on behavior that intends to reduce environmental and social impacts, also referred to as 'weak sustainability' (Roome 2011).

Institutional theory is apt as a lens to study drivers and barriers to sustainability in research, since it recognizes that institutions are sets of rules and practices [like formal regulations, social norms and obligations, and shared understandings and common beliefs (Scott 2008)] that shape the meaning and the perceived appropriateness of social behavior. These regulations, social norms, and shared beliefs strongly influence the way organizations think and act. Using institutional theory as a lens of analysis helps us understand why organizations like NGOs act the way they do, including its drivers and barriers to sustainable conduct. Thus, in our study we build on institutional theory and then identify that 'walking the talk' is a specific situation of complexity and potentially conflicting demands that specifically match the perspective of institutional complexity (Greenwood et al. 2011; Kodeih and Greenwood 2013). Institutional complexity is rooted in institutional theory and focuses on consequences of incompatible prescriptions from formal regulations, social norms and obligations, and shared understandings and common beliefs (Scott 2008), as well as on broader prescriptions beyond those institutional influences.

We explore multiple cases of leading international advocacy NGOs that target sustainability in their mission and advocacy work: international human rights and international environmental NGOs.

We uncover elements that are relevant in institutionally complex situations of 'walking the talk' and add to research on institutional complexity with this specific walk-the-talk context. We find the role played in particular by culturalcognitive and normative factors as drivers of sustainable conduct in the context of advocacy NGOs. Furthermore, we find that these organizations face trade-offs when balancing investments in their advocacy missions with investments in sustainable operations, reflecting ethical dilemmas. In a broader sense, the novelty of this research is that it elucidates the way advocacy or advisory organizations cope, in situations of institutional complexity (Greenwood et al. 2011; Kodeih and Greenwood 2013), with conflicting institutional demands between their role-model function of 'walking the talk' themselves (processes) and accomplishing their advocacy mission (consequences).

\section{Theoretical Background}

\section{NGOs and Accountability}

The number-and influence-of active international NGOs has grown substantially during the last decades, from a few 
hundred in 1951 to over 50,000 in 2011 (UIA 2011; Section 2.9). Therefore, NGOs have been recognized in an international business context as influential key actors (Kourula and Laasonen 2010; Teegen et al. 2004; Waddock 2008). International NGOs act as social, cultural, legal, and environmental advocacy and/or operational groups (Kourula and Laasonen 2010). In this research, we focus on international advocacy $N G O s$ that primarily protect the interests of others and lobby for them, acknowledging that advocacy NGOs may have a hybrid role by also providing operational services (Teegen et al. 2004). Advocacy NGOs are among the social-purpose NGOs that aim to serve particular societal interests, addressing causes such as environmental issues, human rights, or other areas (Doh and Guay 2004; Teegen et al. 2004).

Research on NGOs in the fields of business and society, management, and international literature mainly addresses this advocacy role, activism, and influence on businesses (Kourula and Laasonen 2010), rather than NGOs' internal operations. Yet, the increased organizational size of international NGOs, together with a more competitive funding environment, has meant greater scrutiny of their own performance and accountability (Anheier and Themudo 2005). Even though NGOs are being increasingly questioned about accountability (Jepson 2005; O'Dwyer and Unerman 2008), there has been an emphasis on upward and external accountability to donors (Ebrahim 2005). This focus on financial accountability conceals the role of NGOs as agents of sustainable conduct in their own operations. Therefore, a more holistic accountability perspective that involves a wider range of stakeholders (Unerman and O'Dwyer 2006b, 2010) forms the starting point of this study.

A reason for this limited attention given to NGOs' holistic accountability so far may be the fact that, traditionally, the advocacy role of these NGOs has given them relative immunity from transparency (Teegen et al. 2004). As noted by Fassin (2009, p. 511), some pressure groups and NGOs 'have attained a high degree of credibility. NGOs build their legitimacy on their reputation.' This may quite possibly be related to the fact that trust in NGOs is still relatively high. As reported by the 'special Eurobarometer' on attitudes of European citizens toward the environment, scientists and environmental protection NGOs are the most trusted sources of advice and information on environmental issues (E.C. 2011). Moreover, the 'Edelman Trust Barometer 2016' (Edelman 2016) indicated that NGOs are still the most trusted institutions compared to businesses, government, and media. However, the most recent Edelman barometer data (Edelman 2017) also show that trust in NGOs-similarly to other institutions-has decreased. Moreover, as actors within a larger network of relationships, NGOs may have stakeholders who also call for sustainability in their internal operations, increasing the need to explicitly consider their own sustainable conduct as part of their legitimacy (Suchman 1995) and how they 'walk their talk'.

\section{Institutional Theory and Institutional Complexity}

\section{Institutional Theory}

In prior research, institutional influences have been widely recognized as influential for sustainable conduct (e.g., Bansal 2005; Campbell 2007; Doh and Guay 2006; Glover et al. 2014; Matten and Moon 2008), though often in a corporate context. When studying NGOs' sustainable conduct - an understudied topic so far-institutional theory is a valuable lens that may elucidate idiosyncratic institutional influences due to their specific position of 'walking the talk'. Institutional theory posits that institutions are comprised of three pillars (regulative, normative, and cultural-cognitive) that provide stability and meaning to social life (Scott 2008).

First, the regulative pillar stresses 'a stable system of rules, whether formal or informal, backed by surveillance and sanctioning power that is accompanied by feelings of fear/guilt or innocence/incorruptibility' (Scott 2008). This pillar represents legally enforced rules that influence behavior. Campbell (2007) indicated, for instance, that corporations are more likely to act in socially responsible ways the more they encounter strong state regulation and collective industrial self-regulation. An example of state regulation influencing behavior is tax law that can stimulate investments (Trevino et al. 2008) or philanthropic giving; in other words, it refers to legally sanctioned 'rules of the game' (Geels 2004).

Second, the normative element of institutional theory emphasizes 'the stabilizing influence of social beliefs and norms that are both internalized and imposed by others' (Scott 2008). Normative systems include values, norms, and roles, which work as constraints to social behavior, while certification and accreditation are important instruments that somehow attest the compliance with such values and norms. Since the institutional environment is comprised of normative, legal, and regulatory elements, organizations must conform to them if they are to achieve the legitimacy that is necessary for survival (DiMaggio and Powell 1983). Regarding normative influences, Campbell (2007) argued that corporations will be more likely to act in socially responsible ways if they operate in an environment where normative calls for such behavior are institutionalized in, for example, important business publications, business school curricula, and other educational venues in which corporate managers participate, or if they belong to trade or employer associations, which promote socially 
responsible behavior. All of these can cause a normative climate that is morally governed and that dictates how we are supposed 'to do things' (Geels 2004).

Finally, the cultural-cognitive conception of institutions stresses 'the central role played by the socially mediated construction of a common framework of meaning' (Scott 2008). This includes taken-for-granted routines, or shared conceptions and common beliefs that tend to lead to isomorphism (DiMaggio and Powell 1983). Taken-for-granted routines are based on the notion of 'the way we do those things' (Scott 2008) and routines that are natural to the organization. Because of such cultural-cognitive influences, Kostova and Zaheer (1999) indicated that organizational subunits are likely to encounter greater challenges to establish and maintain legitimacy in their host environments in comparison with domestic firms; this is due to stereotyping and different standards applied to foreign firms by the host environment.

Institutional theory suggests that institutional rules act as myths that are incorporated by organizations, who thereby gain legitimacy, resources, stability, and enhanced survival prospects (Meyer and Rowan 1977). Legitimacy reflects congruence between the legitimate entity's behavior and the shared beliefs of some social groups. Internal legitimacy reflects the acceptance for an organizational strategy by its participants (insiders), whereas external legitimacy urges organizations to comply with expectations and norms of stakeholders who act outside the organization (e.g., Drori and Honig 2013). For example, for multinational organizations legitimacy is important for gaining resources that are vital for growth and survival. Because of the structural complexity of those multinational organizations, a foreign subsidiary is situated in both an external (foreign) and an internal environment and requires both internal legitimacy and external legitimacy, needing resources and support from both environments (cf. Lu and Xu 2006). The external legitimacy of a foreign subsidiary is its acceptance and support by host-country institutions, whereas internal legitimacy refers to its acceptance and support by the internal organization (parent organization and other subunits) (Kostova and Zaheer 1999).

\section{Institutional Complexity and 'Walk the Talk'}

The relevance of institutional theory within the context of sustainable operations by NGOs lies not only in the link between the quest for legitimacy, but also in the idea that organizations with missions that go beyond profit maximization are subject to idiosyncratic institutional forces. In the case of advocacy NGOs that might be scrutinized if they are not 'walking their talk,' those forces are likely to pose conflicting demands. When organizations have to cope with such conflicting institutional demands, including those coming from the regulative, normative, and culturalcognitive pillars (Pache and Santos 2010), they face a situation of 'institutional complexity' (Greenwood et al. 2011; Kodeih and Greenwood 2013). Kostova and Roth (2002) highlighted how applying institutional theory to the case of multinational organizations evidences the specific complexity that these organizations face in their attempts to leverage practices on a worldwide basis. Here the tension appears between the need for internal objectives and norms for global integration, on the one hand, and adaptation to local norms and expectations on the other.

An organization's position within a field influences the complexity that it will encounter (Greenwood et al. 2011). Organizational characteristics like its structure and identity can make it particularly sensitive to certain prescriptions (like external norms and expectations), and less so to others. For instance, some highly visible organizations may be especially scrutinized by stakeholders advancing particular prescriptions. Paradoxically, the same organizations, because of their size and resources, may be insulated from institutional pressures in a way that is unavailable to other organizations (Greenwood et al. 2011), resulting in a kind of immunity.

For advocacy NGOs, their primary mission related to certain sustainability issues (such as environment, human rights) in particular may influence the focus of those organizations' approach toward sustainability (Simaens and Koster 2013). NGOs' advocacy work may raise internal and external expectations about their own internal behavior and make those organizations vulnerable in case this behavior is not aligned with what they tell others to do (such as potential accusations of hypocrisy). NGOs can be expected-by themselves or by external parties-to conform to the rules they set for others. Parties that aim to obstruct NGOs' work (Unerman and O'Dwyer 2006a) get chances to pinpoint inconsistencies if NGOs do not 'walk the talk' and harm their legitimacy. However, NGOs also face upward accountability to devote their scarce time and resources to their primary advocacy work, more than to the internal organization. Thus, this 'walk-the-talk' context in which advocacy NGOs operate brings a specific situation of complexity and potentially conflicting demands, matching the notion of institutional complexity.

The way organizations cope with such complexity is addressed in very few empirical studies, and further examination of how organizations respond to conflicting demands is needed (Kodeih and Greenwood 2013) since responses to institutional complexity may affect legitimacy and even organizational survival (Greenwood et al. 2011). Trade-offs, negotiations, distinctive capabilities and the careful balancing of resources, stakeholder interest, and strategic sourcing have been raised in research as requirements to cope with institutional complexity (Vermeulen 
et al. 2016). Hence, these coping mechanisms—such as trade-offs-result from the institutionally complex situations which organizations face and in which incompatible influences need to be embedded. This study addresses this area that is recommended for further research (Kodeih and Greenwood 2013) in the complex context of sustainability advocates and their internal conduct. However, in a broader sense, institutional complexity around 'walking the talk' may also affect other advocacy or advisory organizations. For instance, advocates, consultants, or other organizations that tell or advise others what to do need to balance their main activities in an institutionally complex setting.

\section{Research Methods}

\section{Research Design}

We aim to extend theoretical insights into how advocates are driven to practice what they tell others to do, since in our cases we study sustainability advocates who drive selfregulation of sustainable behavior of others. This is an area that could be experienced as sensitive due to potential scrutiny. Qualitative methods, like case studies, allow us to come close to this potentially sensitive phenomenon (Bansal and Corley 2011) and to uncover paradoxes (Doz 2011).

Our exploratory research is based on multiple case studies (Yin 2009), in total consisting of a set of ten NGO offices of three international advocacy organizations. These ten NGO offices are the units of analysis. A sampling of multiple cases enables cross-case comparison and adds confidence to findings since its validity is strengthened (Miles and Huberman 1994).

Purposive theoretical sampling in the selection of cases is used to facilitate theoretical generalization (Eisenhardt 1989; Miles and Huberman 1994). Three criteria have been used for case selection. The first criterion was the mission type of the NGOs. Especially for advocacy NGOs that tend to act as pressure groups in certain areas (Handy 1990), such as environment or human rights, it becomes interesting to explore those aspects in their own internal operations.

The second criterion was related to organizational issues. Selected NGOs are membership-based, have an international working area and an organizational setup with country organizations so that a similar complexity in governance, operations, and reporting issues is in place.

The third selection criterion considered size and resources. Organizations with a global annual income of at least 200 million Euros were selected. Firm size matters when it comes to sustainability-related behaviors (Gallo and Christensen 2011), and the conduct of larger organizations with a substantial income might get more attention from its own stakeholders and more severe requests for accountability (Anheier and Themudo 2005). Next to that, bigger organizations should be able to spend more on managing internal conduct and reporting.

These criteria have been used at two levels: first at the NGO level and then at the country organization level. This two-level procedure resulted in the selection of ten NGOs, embedded in two major environmental NGOs (acronyms ENV I and ENV II), and another major NGO focused on human rights and the social dimension of sustainability (acronym SOC). Although anonymity was not explicitly requested by the NGOs, we use acronyms for the organizations in order to focus on the data rather than on the organizations themselves.

Table 1 provides an overview, per office, of some main characteristics of the ten individual offices. In this paper, we focus on the commonalities regarding drivers and barriers to sustainable conduct in sustainability advocacy NGOs.

\section{Data Collection and Analysis Methods}

Combined data collection methods are used in order to enable triangulation and stronger building of variables and propositions (Barratt et al. 2011; Eisenhardt 1989; Yin 2009). In order to enhance reliability of the case studies, a protocol was developed before data collection took place (Barratt et al. 2011; Eisenhardt 1989; Yin 2009). Minor improvements in the protocol were made in-between replications.

\section{Interviews}

Interviews conducted with individuals who were selected as knowledgeable representatives of their offices in the area of sustainable operations were the main source of information for each case, in addition to organizational reports and information from external sources. Table 2 presents the data that was collected and the way in which these data have been applied in our inductive analysis.

The interviews provided valuable information about each office, including personal experiences, interpretations, and views of interviewed individuals (see also Orr and Scott 2008). The semi-structured interviews were based on an interview protocol (this protocol and the interviewee list can be obtained from the authors upon request). Interviews were held at the international (head) offices (ENV I-INT, ENV II-INT, SOC-INT), the Dutch national organizations (ENV I-NL, ENV II-NL, SOC-NL), and the organizations from the UK (ENV I-UK, ENV II-UK, SOC-UK). The Dutch and UK national organizations were among the major national fund-raising organizations for each of the 
Table 1 Main characteristics per organizational unit

Outlines of sustainability approach and practices

\section{ENV I-INT}

Located in the Netherlands; coordinates its international policy and strategy. Both staff and management support sustainable conduct within the office. Sustainability criteria are an integral part of detailed procurement procedures. Several measures have been taken for making a green office, ranging from strict travel policies to sustainable IT equipment. In terms of sustainability reporting, ENV I-INT coordinates the international annual report, as well as part of the reporting to the INGO Accountability Charter

\section{ENV I-UK}

Has explicitly incorporated sustainability in its operations for years. A detailed CO2 accounting system has been developed internally in order to measure impact and to introduce $\mathrm{CO} 2$ budgets, next to financial budgets. An environmental purchasing policy is in place (replaces ENV I-UK's sustainability policy that was spread over six different documents). An environmental report was published in 2009,2010

\section{ENV I-NL}

Has been working on environmental operations. Policy includes, for instance, not to use PVC in buildings, to use environmentally conscious building wood (FSC wood) and to buy food from sustainable vendors. An environmental policy for internal use was written around 2005. Update started in 2009 to formalize and to extend its sustainability policy based on ISO 26000 . There is a sustainability section in the 2010 annual report. Reporting directly to the INGO Accountability Charter

\section{ENV I-GM}

Recently developed a code of conduct and guidelines with, e.g., sustainability policies for travel and procurement. Sustainability was already integrated in daily practice before; hence, central guidelines were not considered to be urgently needed. There is no sustainability report or section yet, other than what is covered by ENV I-INT in the INGO Accountability Charter. Reporting is no priority and was awaiting decisions around centralizing reporting to INGO Accountability Charter

\section{ENV II-INT}

Located in Switzerland, it coordinates network of offices around the world. At its own premises, building and operations have been greened. In addition, they joined an initiative of their Finnish organization to green their office. In this program, energy, travel and transportation, procurement, food, waste and recycling, water, biodiversity, energy, environmental awareness are being monitored. No external sustainability report

\section{ENV II-UK}

Has been managing sustainability for its internal operations explicitly for two decades. They have an environmental team, a dedicated environmental manager, an environmental policy and environmental management system (ISO 14001), and an environmental steering group in place. Environmental reports have been published for over a decade

\section{ENV II-NL}

One of the biggest national organizations within ENV II that is able to raise funds and work quite independently. Office building is relatively young and serves as a corporate sustainability flagship. A sustainability policy was developed in 2008, and projects are set up annually based on this policy, e.g., involving procurement. The section on sustainability in the Dutch annual report is also based on the structure of this policy and reports about those projects

\section{SOC-INT}

London based with about ten small satellite offices around the world (some with just 2 or 3 staff). A procurement policy is developed to formalize procurement processes for the London office, yet no central sustainability policy or management drive for sustainable conduct is found. Procurement and facilities management staff integrated sustainability aspects in their own work. In terms of reporting, there is the contribution to the INGO Accountability Charter

\section{SOC-UK}

Has an office in London and 3 small satellite offices in the UK. In the London office, there is a drive both from management and from staff and donors to work in a sustainable way. Management aims to be an exemplar office among other London NGO offices. The environmental policy statement indicates selected areas for attention (including travel) and a procurement policy with a section on sustainable procurement. The UK section published an annual report in 2010, including a sustainability section following GRI guidelines and it contributes data to the INGO Accountability Charter

\section{SOC-NL}

A working group developed a sustainability policy for 2009-2010, as a first phase to update sustainability practices (policy evaluation and revision in 2011). Work around sustainability internally driven by both management and staff by 'practice what you preach' awareness. In their annual report and on the internet, sustainability reporting included in annual report. It contributes to the INGO Accountability Charter

three NGOs. Considering its added value for the research, we also conducted an interview with the German office (ENV I-GM). Interviews took place mainly by visiting sites in the Netherlands and the UK, complemented with phone interviews that had to take place outside those countries. 
Table 2 Data collection and analysis

\begin{tabular}{|c|c|c|}
\hline Source & Frequency & Analysis \\
\hline Archival data & $\begin{array}{l}>30 \text { annual reports, internal guidelines, other internal } \\
\text { publications (as available in 2011) }\end{array}$ & $\begin{array}{l}\text { Screening for [1] organizational characteristics and data } \\
\text { and [2] data on sustainable conduct } \\
\text { Indicative for limited interest in external reporting }\end{array}$ \\
\hline Interview data & $\begin{array}{l}18 \text { semi-structured interviews, typically lasting } 1 \mathrm{~h} \text { but } \\
\text { ranging between } 0.5 \text { and } 2 \mathrm{~h}(2011) ; 19 \text { interviewees }\end{array}$ & $\begin{array}{l}\text { Coding of data and clustering in themes: } \\
\text { Sustainability practices } \\
\text { Institutional influences (both drivers and barriers) } \\
\text { Organizational aspects }\end{array}$ \\
\hline $\begin{array}{l}\text { Secondary data analysis } \\
\text { through newspaper } \\
\text { articles }\end{array}$ & $\begin{array}{l}1145 \text { articles with name of ENV I, ENV II or SOC1 n } \\
\text { title }(2005-2010)\end{array}$ & $\begin{array}{l}\text { Screened and categorized as among others } \\
\text { Reported in advocacy role } \\
\text { Attacked on internal sustainability issues used as } \\
\text { indicator for public reporting about and perception of } \\
\text { NGOs }\end{array}$ \\
\hline $\begin{array}{l}\text { External sources on } \\
\text { NGO's }\end{array}$ & Various sources & $\begin{array}{l}\text { Indicative of societal trust in NGOs like } \\
\text { Yearbook of International Organizations } \\
\text { Edelman Trust barometer }\end{array}$ \\
\hline
\end{tabular}

Interviews per office included the persons responsible for (sustainable) operations and (sustainability) reporting. Functional backgrounds of these individuals varied per organization, including facilities and/or purchasing managers (8), financial managers (4), development or organizational directors (4), an environmental manager, a legal counsel, and an accountability manager. The 18 interviews with 19 interviewees typically lasted $1 \mathrm{~h}$, but varied from $30 \mathrm{~min}$ to $2 \mathrm{~h}$.

Interviewing individuals from several functional areas provides multiple approaches to the same subject and the possibility for triangulation, or for enhancing reduction in social desirability biases (Podsakoff et al. 2003). All interviews were conducted by the first author. Interviews mainly took place in person, with open-ended questions as a starting point, not limiting the interviewee to raise new aspects that could be relevant. All interviews were recorded, transcribed with F4 software, coded, and analyzed with the assistance of MAXQDA software.

\section{Coding}

Coding of transcripts was done independently by two researchers in order to maximize reliability (Barratt et al. 2011; Eisenhardt 1989; Yin 2009). Various measures were taken to maximize coding reliability. First, both coders set up the research and worked closely together from the beginning, developing a mutual understanding of its context. Second, the list of codes was drafted in advance and discussed in detail to facilitate and reach a shared interpretation. In particular, the institutional factors needed discussion because of their often tacit character. The institutional categories were based on the institutional pillars as outlined by Scott (2008, p. 51) and were outlined for coding as follows: (a) Influences were coded as 'regulative' when they were explicit and connected to regulative rules and conformation to legal requirements, laws, governance systems; (b) 'Normative'-coded fragments refer to largely tacit social obligations which are connected to binding expectations and norms, evaluation, conforming to ideals and values, conventions, roles, taboos, practices, protocols; (c) 'Cultural-cognitive' refers to highly tacit constitutive schemes, beliefs, taken for grantedness, shared understanding and is based on cognition, conforming to models and related to mental models, identities, schemas, beliefs, scripts.

The list of codes was enhanced during the analysis (Miles and Huberman 1994), and hence, a combination has been used from: (i) ex ante-listed codes primarily drawing on institutional theory (such as normative, cultural-cognitive, and regulative, drivers and barriers) and (ii) codes that emerged from the raw data, for which an open possibility was built in (see code structure in "Appendix 1").

A third measure to maximize coding reliability relates to inter-coder differences. From the transcripts, all coding differences were traced and addressed in detail by the coders until a consensus was reached. This was done [i] by adapting codes in fragments where one or both coders reached a new perspective on the data, [ii] by adapting the length of coded segments, or [iii] by assigning multiple codes to some fragments, whichever was most appropriate. The coding process continued until discussions about differences in coding and interpretations of data were resolved and a full consensus was reached. 
After the coding, 2624 fragments were coded and agreed by both coders. Within-case descriptions and abstracts were made to analyze the main characteristics and to gain insights per case. Related to the exploratory character of the research, emerging patterns were identified to provide insights into drivers and barriers for NGOs toward sustainable internal conduct. Each researcher separately combined codes and looked for patterns within and among the ten offices. Major categories as a basis for analysis were codes related as [1] drivers to practice, [2] barriers to practice, [3] drivers to reporting, and [4] barriers to reporting. These four categories were split into sub-categories according to institutional pillar and organizational influence. Both coders separately analyzed the main findings per sub-category. These analyses were combined and contrasted in one analysis document.

In order to challenge and reevaluate patterns that were found in the analysis document, the code relations browser from MAXQDA was applied to the data. This browser did not compare weights of coded fragments, but frequencies of code relations indicate how often related elements are brought forward. Frequencies varied substantially (see some code relations tables in "Appendix 2") and supported the researchers' conclusions that regulative drivers hardly play a role in sustainable conduct and that drivers for reporting are weaker than drivers to behave in a sustainable way. No conclusions were based solely on these frequencies.

Strength of drivers was fully based on the (doublecoded) authors' in-depth analysis of coded data per interview. The MAXQDA code matrix (see "Appendix 2") provided a very useful means for a quick check to see whether data made sense. For this purpose, we reviewed the frequencies of coded interview segments in the MAXQDA code matrix browser. Still, we did not use this matrix in quantitative terms, but rather in qualitative terms to confirm the authors' understanding of the data and its content analysis. The fact that some institutional drivers were more commonly mentioned as drivers of sustainable conduct in the interviews was taken as reinforcing evidence of the strength of the driver.

\section{External Data Sources}

Besides the data from the organizations themselves (interviews and self-reported documents), external data sources were also used to investigate public reports about pressures from and to the organizations. Through a secondary data analysis in the Lexis-Nexis database, international newspaper articles dating from 2005 to 2010 that targeted ENV I, ENV II or SOC (in the title) were selected. All 1145 articles were screened and categorized as [1] NGO is reported in an advocacy role; [2] NGO is being questioned or being attacked on its social conduct (environmental or social aspects); [3] NGO is being questioned or being attacked on other conduct; or [4] other (NGO neither as advocate, nor being attacked or questioned). These categorized data provide an indicator about the public perception of and reporting about the NGOs in our research.

\section{Tabulation of Data}

Figure 1 shows the connection between raw data and related core concepts that resulted from the data analyses. The internal and external legitimacy-seeking influences mainly had a driving character, whereas internal trade-offs compromised the principles for sustainable internal conduct. In addition, immunity indicated that NGOs in general had hardly any scrutiny of their sustainable conduct.

The organizational facts in the papers were validated with the NGOs, and no amendments or corrections were proposed by their contact persons.

\section{Results}

In this section, we develop an exploratory analysis across the ten cases, focused on our research question: What are the drivers and barriers to sustainable conduct of NGOs that are sustainability advocates?

Sustainable internal conduct varies considerably across the ten organizational units included in our research. Remarkable differences are found internally among the sustainability approaches of different offices, and even among offices of the same NGO. Each office operates quite independently, generally without strict central guidelines or imperatives, as shown in methods section in Table 1.

Table 3 summarizes the presence of a sustainability policy and an authors' analysis of the character and perceived strength of the institutional drivers toward sustainable conduct.

As an example of how the drivers given in Table 3 are categorized, we briefly illustrate the motivation of ENV I-UK. In this particular case, we categorized institutional influences as (i) nonexistent/unreported regulative drive; (ii) a major cultural-cognitive drive; and (iii) a medium normative drive. First, in general, regulative drivers were insignificant (please refer to "Appendix 2"), but in the specific case of ENV I-UK, this type of driver was not encountered or reported at all. Second, in relation to the cultural-cognitive drive, ENV I-UK reflected first of all both management and staff involvement, and next to that a strong intrinsic motivation and taken-for-granted position: Our interviewees indicated and also illustrated that their staff are 'committed and passionate' about sustainability. 


\section{FIRST ORDER CLASSIFIED DATA}

- ENV I_UK: "people who work for these organizations are committed and passionate, so there is already a level of motivation that may be higher."

- SOC_UK: "our employees are very keen, very keen, and you would expect that because of the field they work in... this is just kind of the nature of the person they are... so they are very keen..."

- ENV I_GM: "We are pretty much on the extreme end of trying to be very pure, independent and that also probably makes it different, makes us potentially very fragile, so we need to focus a lot on walk the talk and on being environmentally correct, just in case anybody asks."

- ENV II INT: flights are still necessary to do the advocacy work: "flights is the biggest $\mathrm{CO} 2$ emissions that we do have and it is a problem, but we are a global organization and we need to travel and meet people and see projects and plan the future"

- ENV I_NL: "if we do an action and for the action it is needed to hire 10 or 20 cars, we hire 10 or 20 cars..."

- SOC_UK: "people give us money for human rights... and they don't really want too many diverts away from that... although equally our members want to see that we are environmentally sustainable...."

- ENV I_INT: the NGO cannot justify "having a completely beautiful single dancing green lovely office, when all of our supporters' money has gone to doing that, as opposed to campaigning, so it is a very real trade-off..."

- ENV II_NL:"We think that people see us as a good example"

- ENV I_GM:"...the public assumes that you are clean and that you are complying"

- SOC_INT: "there is no one telling us that we need to improve... we need to say that to ourselves".

- Archival data analysis

\section{SECOND ORDER THEMES \\ CORE \\ CONCEPTS}
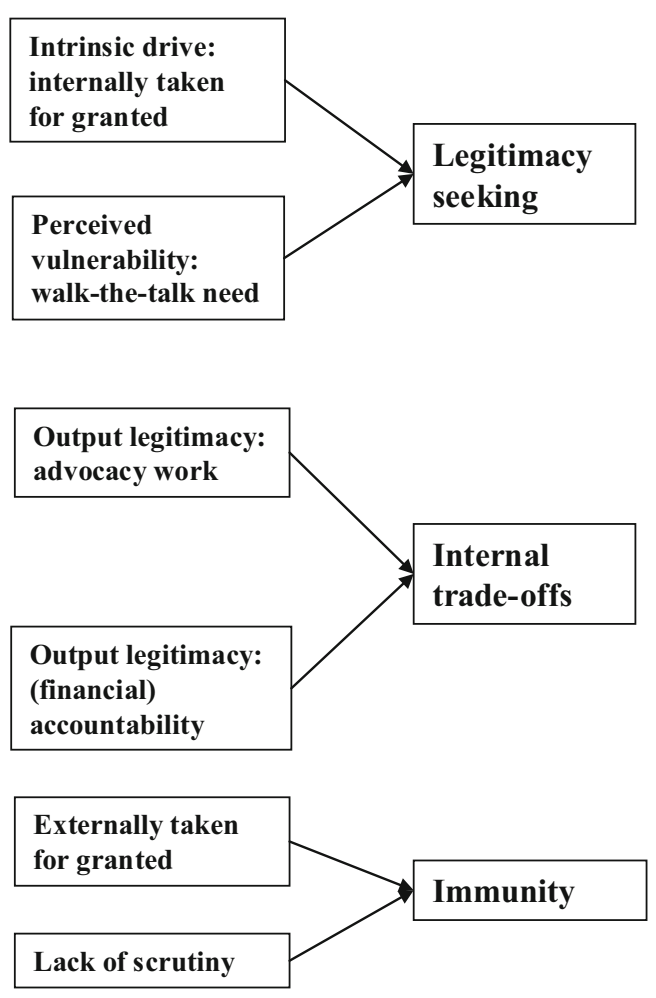

Fig. 1 Connection between raw data and core concepts

Finally, the normative drive was also encountered, although less prominently. Firstly, it was, for instance, reflected by the fact that funders' expectations on how to spend money were acknowledged and taken into account, and secondly by a small review of sustainable internal conduct, which the organization made available publicly. A third sign of a normative drive was the struggle around which norms apply to judge what products could be considered 'sustainable' (like the Carbon Trust that rates 'kettles').

Although organizational practices differed among the ten advocacy NGOs, our cross-case analyses revealed commonalities in the underlying complexity. On the one hand, regulative drivers were insignificant, while both cultural-cognitive and normative drivers were encountered and manifested mainly in a taken-for-granted attitude from the staff and an awareness of others' expectations. On the other hand, trade-offs between advocacy work and work on sustainable internal conduct were also found.

These findings derived from three core concepts emerging from the raw data (see Fig. 1). First, a legitimacy-seeking stance-both internally and externally- related to the three institutional pillars (cultural-cognitive, normative, and regulative); second, trade-offs faced by NGOs; and finally, the organizations' immunity. These concepts are further explained next.

\section{Cultural-Cognitive Drivers}

The cultural-cognitive pillar was a determining factor and driver for the advocacy NGO offices' internal sustainability of operations. The sense of 'taken for granted' ('of course we strive to work in a sustainable way') was commonly mentioned in the interviews as an important driver for management and employees to behave in a sustainable way. The cultural-cognitive drivers included the shared motivation of the organization's employees to behave in a sustainable way as 'the way we do these things,' which is demonstrated in the example of ENV II-UK:

Some mornings... our boilers are so inefficient... you know... the temperature is about 16 degrees... and we have to wait for it to gradually warm up... Even though boilers come on you know mid-night to 
Table 3 Drivers to sustainable conduct per organizational unit (indicative)

\begin{tabular}{|c|c|c|c|c|}
\hline NGOs & $\begin{array}{l}\text { Cultural } \\
\text { Cognitive }\end{array}$ & Normative & Regulative & $\begin{array}{c}\text { Sustainability } \\
\text { policy }^{\mathrm{a}}\end{array}$ \\
\hline ENV I-INT & & & 0 & Yes \\
\hline ENV I-NL & & 0 & 0 & Yes \\
\hline ENV I-UK & & & $\bigcirc$ & Yes \\
\hline ENV I-GM & & 91 & 0 & Yes \\
\hline ENV II-INT & 0 & 01 & $\bigcirc$ & Yes \\
\hline ENV II-NL & D & 01 & 0 & Yes \\
\hline ENV II-UK & 001 & 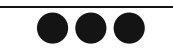 & 0 & Yes \\
\hline SOC - INT & 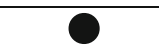 & 0 & O & No \\
\hline $\mathrm{SOC}-\mathrm{NL}$ & 00 & 0 & 0 & Yes \\
\hline SOC - UK & 001 & 001 & 0 & Yes \\
\hline \multicolumn{5}{|c|}{ 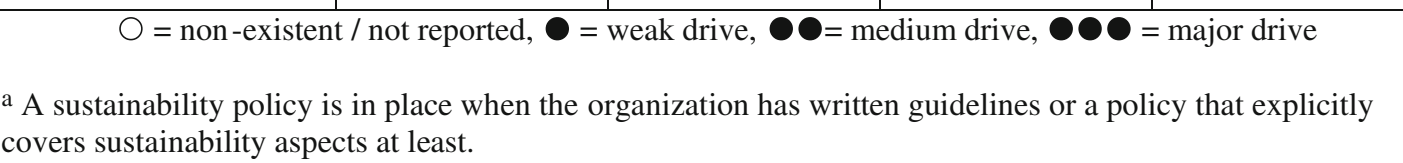 } \\
\hline
\end{tabular}

start... and yet we hardly have any complaints because people know that the alternative is to buy new boilers or to have the boilers on $24 \mathrm{~h}$ a day and they know that's not sustainable.

A personal will and intrinsic drive played a key role in decisions concerning sustainability, indicating a search for internal legitimacy. For example, ENV I-UK indicated that 'people who work for these organizations are committed and passionate, so there is already a level of motivation that may be higher.' SOC-UK indicated that 'our employees are very keen, very keen, and you would expect that because of the field they work in... this is just kind of the nature of the person they are... so they are very keen...'.

The 'taken-for-granted' approach appeared to be somehow skewed toward the organizational mission. Although all organizations acknowledged social and environmental aspects as part of sustainability, there was evidence that sustainability aspects that were closely related to their organizational mission were prioritized. An explicit awareness of this focus was mentioned in five cases. For instance, SOC-UK mentioned: '...purchasing decisions are skewed. We do skew heavily on the labor standards... other organizations might skew towards environmental standards, depending on where they are.'

In addition, the way in which practices started to develop was mentioned in some cases, pointing to a natural development where sustainable practices spontaneously evolved and were naturally supported by management. These processes confirm the taken-for-granted feeling, as illustrated by ENV I-NL: 'it was not really defined as a policy... it was a way of working, which was really into the minds and hearts of everybody.'

Almost all organizations gave evidence that they looked at other NGOs' internal conduct to learn from it or to benchmark their own behavior. Seven organizations 
evidenced an even more active exchange of practices with local peers or other NGOs. As noted by SOC-UK, ' $m y$ peers... all the facilities managers who are running buildings, we are quite often going into each other's buildings just to have a look at what they are doing (...) and we want to show off our building too.' SOC-UK also highlighted that '... it's interesting and it's good to be able to share... share knowledge, but there is quite a lot of pride in that as well...'. Contacts with local peers to exchange sustainability practices in general outweighed contacts and benchmarks with other offices within their own NGO.

Finally, all organizations had in common the fact that when it came to reporting on sustainability - as part of their sustainable conduct-, cultural-cognitive elements did not seem to play a role. None of the units provided evidence that sustainability reporting was something taken for granted that naturally needed to happen, whereas such cultural-cognitive drivers were generally in place for sustainable behavior in varying strengths across the organizational units.

\section{Normative Drivers}

Next to cultural-cognitive elements, normative drivers played an important role for the analyzed offices. There were expectations and values set by others for the organization, which were a sort of social obligation. It was as if these advocacy NGOs were looking for external legitimacy. In two cases, organizations proactively asked stakeholders for their opinion, and members' expectations were frequently mentioned, such as in this example by SOC-UK:

People give us money for human rights... and they don't really want too many diverts away from that... although equally our members want to see that we are environmentally sustainable and although we are not actively damaging the environment I think they would be upset if they heard that we are doing stuff that was damaging to the environment....

There was a sense of perceived vulnerability as they felt they needed to 'walk the talk'. The NGO's own mission played a key role in relation to external stakeholders' expectations about its sustainable conduct. For the outside world, the organization's mission would be reflected implicitly by the organization's internal behavior. This would reveal its mission as an expectation toward the NGO itself. All organizations mentioned this need to practice what they told others to do, since not doing so was related to potential reputational damage, as stated by ENV I-Germ:

ENV I is the leading environmental organization, so the pressure so to speak on walk the talk might be higher than on the Doctors Without Frontiers... We are pretty much on the extreme end of trying to be very pure, independent and that also probably makes it different, makes us potentially very fragile, so we need to focus a lot on walk the talk and on being environmentally correct, just in case anybody asks. We cannot afford anything like that to happen to make the headlines of the news. So that makes us probably different from other NGOs.

In needing to 'walk the talk,' some advocacy campaigns even caused an internal 'wake-up call'. This is what makes advocacy NGOs so unique compared to firms and even other NGOs. Sometimes the campaigns themselves instigate internal changes without any explicit external request. For instance, ENV I-Germ used a campaign against a company using a coal power plant as a trigger for their own conduct, even though the power consumption of an NGO office was modest in absolute terms.

Furthermore, there were sustainability standards that the offices selected to comply with. Those standards set criteria and consequently drove internal conduct. Some organizations chose standards (norms) with which to comply as a guideline, while some developed their own way of working. Three types of external standards were found: [1] at a product level in all organizations, standards and labels were found for the use of, for instance, FSC-certified paper, MSC fish, or Fair Trade products; [2] at an organizational level in only one case, international certifiable management standards like ISO 14001 (environmental management) were found, whereas one other organization (ENV I-NL) started to use ISO 26000, which are guidelines for social responsibility; and [3] reporting standards on either the international or national level.

Regarding the other element of sustainable conduct, drivers to sustainability reporting were in place to a lesser extent than drivers to sustainable practices. Still, the 'walkthe-talk' pressure was being mentioned by the interviewees, since NGOs ask businesses to be transparent about their operations.

\section{Regulative Drivers}

Examples of the regulative pillar were rarely found in the interviews. In general, regulations did not seem to play a significant role in any of the organizational units.

\section{Institutional Barriers}

When it came to institutional influences that withheld NGOs from sustainable behavior, all interviewed organizations mentioned compromises or trade-offs because of competing activities such as the NGOs' main advocacy 
work. Rather than encountering resistance against sustainable conduct, it was the setting of priorities that in some cases slowed down efforts to enhance sustainability in internal operations.

First, cultural-cognitive influences were an important driver to sustainable practices in general, but at the same time they were seen as limiters of further sustainable conduct. Hence, although interviewees indicated that employees in their organization were disciplined and motivated to behave in a sustainable way, some exceptions were mentioned where it was challenging for the organizations to motivate staff. The cultural-cognitive drive varied per organization, but the exceptions to a sustainable conduct driven by cultural-cognitive reasons were generally those cases where convenience, efficiency, or existing ways of working on advocacy work would be compromised if more sustainable practices had to be adopted. For instance, ENV II-INT indicated that flights were still necessary to do their advocacy work: 'flights is the biggest CO2 emissions that we do have and it is a problem, but we are a global organization and we need to travel and meet people and see projects and plan the future.

Some limitations to sustainable conduct within an organization resulted from scarcity of resources and (financial) accountability for expenses. Trade-offs needed to be made, as mentioned by SOC-UK: 'obviously, we can spend our resources on a Middle East campaign for human rights or measuring carbon emissions from our business travel and you know... that's a real... that's a real choice...'. In many reported trade-offs, supporters' expectations were mentioned. ENV I-INT indicated that they could not justify 'having a completely beautiful single dancing green lovely office, when all of our supporters' money has gone to doing that, as opposed to campaigning, so it is a very real trade-off...'.

Second, normative influences, which have been reported as important drivers, also had a decelerator role. In fact, norms and expectations of external stakeholders had a distinct influence on the trade-off between internal sustainability conduct and advocacy work. For instance, some organizations felt the pressure from donors in the use of money (for example, 'our supporters want us to use the best products but they also don't want us to spend too much money on them (...) so we have use that wisely as well...,' GP UK). The concern about making the best use of the supporters' money was present in some interviews, referring to the need to balance advocacy work with their own sustainable conduct that often requires some upfront investment (such as efficient facilities and heating systems or water and energy savers). At the same time, being organizations with sustainability-related missions and working on the 'good cause,' NGOs seemed to have natural legitimacy. Stakeholders considered it logical that NGOs behaved in a sustainable way and thus did not scrutinize them on those aspects. As stated by ENV II-NL, 'We think that people see us as a good example'; similarly, SOC-INT stated: 'there is no one telling us that we need to improve... we need to say that to ourselves.' The quite explicit example in this respect, quoted in the first lines of this paper, comes from ENV I-GM, which wanted to be certified with ISO 14000, but was advised to spend their money otherwise because they were trusted anyway.

It is important to note that none of the NGOs proved to be seriously questioned by external stakeholders about their sustainable conduct, and this may have reduced the need to emphasize internal sustainability. This lack of scrutiny was confirmed by the findings from our secondary data search. Out of the 1145 articles published between 2005 and 2010, only about 60 referred to some sort of criticism toward the NGOs, and they hardly specifically referred to the NGOs' own sustainable conduct. Rather, they referred mostly to criticism regarding the way these organizations developed their mission, such as their organizational approach to the issues addressed and their disregard to law when campaigning (mostly ENV I), disregard of national legal and social context (mostly SOC), or issuing of misleading information (all three NGOs).

There were a few examples specifically related to sustainability, such as the ones in 2005 featuring ENV I, involving a ship that hit a coral reef in the Philippines, and a polemic prize (trips to 'paradise' destinations) created by the USA office for those recruiting new members or campaigning against nuclear power. This prize was criticized by other offices, reinforcing the different approaches of offices around the world. In three other articles, some reference was made to the potential indirect social impacts to the local communities caused by the NGOs' campaigns, such as loss of jobs.

Finally, the regulative institutional factors slowing down sustainable practices, just like those driving them, are anecdotal. Only in one case it was mentioned that there were fiscal benefits, where VAT advantages boosted printing magazines instead of sending them by e-mail or making it smaller.

\section{Discussion}

Advocacy NGOs are important players that drive other organizations to behave in a sustainable way. This research aims to understand what drives or withholds NGOs to operate in a sustainable way internally and how institutional theory and institutional complexity could explain these drivers or barriers.

For other organizations, a positive relationship has been found between sustainability aspects mentioned in firms' 
mission statements and internal practices, such as worklife initiatives (Blair-Loy et al. 2011) or stakeholder management (Bartkus and Glassman 2008). For advocacy NGOs, it can be argued that this relationship between advocacy mission and internal conduct could be even stronger. Our findings disentangle, from an institutional point of view, drivers and barriers to sustainable conduct of NGOs acting as sustainability advocates.

\section{Internal Legitimacy: Taken for Grantedness}

A significant internal taken-for-granted motivation was found in the majority of cases, driving sustainable behavior because of its self-evidence for the employees. The wish to behave-in line with the mission-in a sustainable way was indicated to be something natural for most organizations, albeit often biased toward the own mission area (for instance, missions for environment or social conditions or human rights). Yet, there was broad recognition that sustainability outside the mission area was also important. Those 'natural drivers' have cultural-cognitive characteristics (Scott 2008) that drive the NGO's sustainable conduct, encompassing moral motives for sustainable behavior. Contrary to this, previous research shows that for firms, among a broad variety of drivers for sustainable conduct (Aguinis and Glavas 2012; Bansal 2005), the business case of sustainable behavior and maximizing profits often play a major role (Ambec and Lanoie 2008; Campbell 2007; Hopkins et al. 2011; Kiron et al. 2012). Additionally, for organizations that do not have a sustainability-related mission, cultural-cognitive drivers appear to be lower in general (see also Hoejmose and Adrien-Kirby 2012; Walker et al. 2008). In contrast, the NGO representatives in this research indicated, as a key motive, that sustainable behavior was something natural for their organizations which had missions beyond profit maximization. As noted earlier, this intrinsic drive played a key role in decisions concerning sustainability, suggesting a search for internal legitimacy. Based on our findings, the extent to which the sustainability-related mission and advocacy work of NGOs that act in sustainability enhance internal 'taken for grantedness' related to the need to internally behave in a sustainable way deserves further exploration.

\section{External Legitimacy: Perceived Vulnerability and Immunity}

Next to the cultural-cognitive influences, versatile normative influences were encountered coming from the mission, characterized by a distinct interplay of influences which were specific for those advocacy NGOs (expectations, external values of members, for instance). Two important contrasting influences determine the effect of the normative pillar in the search for external legitimacy, which urges the organizations to comply with expectations and norms of stakeholders who act outside the organization. These are what we name here as 'perceived vulnerability' and 'immunity'.

Related to the 'perceived vulnerability,' all NGO offices perceived that their sustainability-related work and mission increased expectations from others regarding their own conduct. Thus, there were specific norms with which to comply because of their sustainability-related mission. As it was often mentioned, they needed to 'walk the talk'. However, the organizations indicated that they had not really been questioned or challenged on internal sustainable behavior on a large scale, as confirmed by our document analysis of international newspapers. Considering this lack of active scrutiny, the 'need-to-walk-the-talk-perception' points to a sense of exposure to potential scrutiny, which we introduce as the perceived vulnerability of the organization's legitimacy.

From an institutional perspective, this perceived vulnerability tends to be a normative influence (Scott 2008), since the NGOs own advocacy work and norms they apply to others are now perceived as norms that others might apply to the advocacy NGO itself. This perception drives sustainability higher up the NGOs' agenda. Hence, the norms NGOs apply to others seem to have a boomerang function. A clear representation of this boomerang effect comes from campaign work, which in some cases directly urged the NGOs to look at their own conduct. In the case of ENV I, it attacked a global internet service provider with regard to the provider's energy sources, and this created an internal mandate for renewable energy sources. The organization first created their advocacy campaign for other organizations and then reacted to their own campaign as an internal wake-up call.

Our findings suggest that the sustainability-related mission and advocacy work sharpens notions of perceived vulnerability. For advocacy NGOs in the area of sustainability, we find that perceived vulnerability and their legitimacy-seeking approach in turn relate directly to the organization's intentions to behave in a sustainable way themselves. Further research could explore the extent to which the advocate's perceived vulnerability influences the drive to conform to the mission internally.

Besides the perceived vulnerability, the second normative influence related to NGOs' mission was 'immunity'. The NGOs' mission-related legitimacy reduces external scrutiny and direct pressures on sustainable internal conduct. By being not-for-profit-oriented, with socially and/or environmentally oriented missions, legitimacy might automatically be perceived to be guaranteed for NGOs. It is externally taken for granted that those NGOs behave in a 
sustainable way. This legitimacy related to sustainability also reduces the organization's need to report about internal sustainability, so that resources can be used for other purposes (Jepson 2005).

In general, legitimacy is a potentially important driving force and guidance for business conduct in organizations (Singh et al. 1986). In this specific case, however, legitimacy also provides immunity by reducing the need to pay attention to sustainable internal conduct. This immunity is based on this external taken for grantedness (external legitimacy) and a lack of scrutiny (as also appeared in our secondary data search). Thus, in contrast to the earlier discussion on the potential effects of having a sustainablerelated mission and facing perceived vulnerability, this discussion points toward a potential negative influence of the NGOs' sustainability-related mission on its sustainable internal conduct through immunity.

In fact, this lack of external scrutiny suggests that these NGOs are hardly held accountable for sustainable internal conduct. The role accountability plays in the ethical decision making has been explored in the literature (e.g., Beu et al. 2003; Frink and Klimoski 1998). In their study, Beu et al. (2003, p. 91) concluded that, despite what literature suggested, those who were not held accountable at all did not necessarily engage in the most unethical behavior. This touches our discussion on immunity of NGOs in the sense that the immunity felt by these organizations may alleviate their drive to engage in more ethical behavior, which in this case is the sustainable internal conduct. This does not mean that they would behave unethically, rather that it may influence the trade-offs discussed in this paper.

As such — and paradoxically enough — the mission seems to have two opposing effects. On the one hand, NGOs perceive that behaving in a sustainable way is implicitly expected by others implicitly and that not doing so brings a real (reputational) risk. Thus, they need to practice what they tell others to do ('walk the talk'). The notions of sustainablerelated mission and perceived vulnerability bring forward institutional forces that place sustainable internal conduct higher on the NGOs' agenda. On the other hand, that same mission brings legitimacy, which actually seems to prevent NGOs from being scrutinized. Thus, it is mainly the NGOs themselves who feel the need to comply to expectations, rather than stakeholders explicitly asking them to do so. This first effect of 'walking the talk' stimulates awareness regarding the sustainability of internal conduct, whereas the second effect of immunity may influence the trade-off between the direct advocacy work and the internal operations in favor of advocacy work.

In order to address this paradoxical influence of an NGO's mission, we went back to the data and contrasted the 'we-need-to-walk-the-talk' effects in fragments coded as drivers with the 'legitimacy' effects in fragments coded as (normative) barriers to practice, where the NGO's mission enhanced legitimacy and thus immunity. We found the strongest explicit evidence for the first effect. Although not (yet) scrutinized, the NGOs want to have 'their house in order'. The driving effect of 'walking the talk' seems to prevail over potential effects of immunity and the lack of external scrutiny.

\section{Institutional Complexity: Trade-Offs}

Despite the importance of sustainable internal conduct, the NGOs' advocacy activities compete for the same scarce internal resources. This forces NGOs to make trade-offs concerning resources like money and time. Following Le Menestrel and de Bettignies (2002), trade-offs between processes and consequences characterize business ethical dilemmas. The distinctive challenge for the researched NGOs is that in their case the dilemmas are not between economic interests (consequences) and ethical values of business actors (processes) (Le Menestrel and de Bettignies 2002); rather, it is between 'walking the talk' themselves (processes) and accomplishing their advocacy mission (consequences).

Two factors should be taken into account for this tradeoff. The first factor is what Ossewaarde et al. (2008, p. 45) referred to as 'output legitimacy,' defined as the need 'to show how they actually materialize their objectives.' In other words, NGOs need to be able to show the realization of their missions toward stakeholders. Spending time and money on advocacy work might often realize more influential changes than spending those resources on managing internal sustainability. As relatively small organizations, NGOs' internal operations have only a modest sustainability impact (Unerman and O'Dwyer 2006b), whereas their core advocacy work is often mentioned as a core influential driver for others (e.g., Domeisen and Hulm 2006; Haack et al. 2012; Kong et al. 2002; Valente 2012; Van Cranenburgh et al. 2013). This implies that spending time on internal operations would be less efficient in terms of sustainability than spending time on advocacy work and therefore might be more difficult to justify to stakeholders like sponsors (Ossewaarde et al. 2008).

A second factor for NGOs output legitimacy is their financial accountability (Jepson 2005; Steffek and Hahn 2010). NGOs need to be transparent about the way donations are spent. Internal conduct will not be classified as advocacy work and hence should utilize limited resources.

Enlightened by institutional theory, the ethical dilemmas (O'Fallon and Butterfield 2005) and conflicting institutional demands encountered in this study point at the notion of institutional complexity (Greenwood et al. 2011).

The NGOs' mission and primary raison d'être are located in their direct advocacy work. We find that their 
mission also drives sustainability of their internal conduct, referring to a kind of role-model function in which they practice what they tell others to do: behave in a sustainable way. This resembles the link made by Fassin (2009, p. 515) between raison d'être and the 'intrinsically ethical grounds that underpin their (NGOs) foundations.'

The role-model function embodies institutional complexity (Greenwood et al. 2011): conflicting institutional demands inform the organizations regarding how to balance ends (advocacy vs. symbolic function of role model) when means like time and money are scarce (cf. Pache and Santos 2010). The conflicting demands rise between notions of perceived vulnerability and intrinsic drive (for role model) on the one hand, and upward accountability and output responsibility for advocacy work on the other. The need for NGOs to undertake balancing acts is also mentioned by Fassin (2009) in his work on the ethical evaluation of actions taken by NGOs toward 'victim' corporations. The dilemma for those organizations was how to formalize and institutionalize transparency and accountability practices, without losing the essence of their raison d'être. This notion of raison d'être used by (Fassin 2009) resembles the 'walk-the-talk' concept used in this paper, as a NGO's raison d'être should be reflected in the way they act.

Despite the perceived vulnerability, we did not encounter actual cases of external scrutiny. This is in line with the notion that visible organizations may be insulated from (external) organizational pressures (Greenwood et al. 2011; Kraatz and Block 2008). Paradoxically enough, the same type of organizations might be especially targeted by stakeholders, underlining the fragility of their legitimacy (Greenwood et al. 2011).

\section{Conclusions}

Our research question addresses the following question: 'What are the drivers and barriers to sustainable conduct of NGOs that are sustainability advocates?' Even if these findings can somehow be considered as intuitive when it comes to drivers and barriers per se, our research raises two important aspects to the literature: the notion of trade-offs and of immunity of advocate NGOs, who could be expected to walk their talk, in the context of their sustainability practices.

Our contribution to literature is threefold. First, we study drivers and barriers to sustainable conduct in a novel context, and understudied organizations like advocacy NGOs may reveal novel approaches and insights (cf. Pagell and Shevchenko 2014). We refine and extend knowledge about what may drive or refrain an organization's sustainable conduct from an institutional point of view. There is a novel and significant position for cultural-cognitive drivers (see Campbell 2007), as well as for the major paradoxical effect of the NGOs' mission, which stimulates sustainable behavior through 'perceived vulnerability' on the one hand, and on the other hand potentially reduces the need to internally behave in a sustainable way through 'immunity.' Although part of these results might be idiosyncratic for advocacy NGOs, similar drivers and paradoxical effects might be found in organizations in areas such as fair trade, ethical banking, or political organizations with a sustainability focus. For organizations that do not have a sustainability-related mission, cultural-cognitive drivers appear to be lower in general (see also Hoejmose and Adrien-Kirby 2012; Walker et al. 2008), and there is no role-model function at stake in their trade-offs between their mission and sustainable internal conduct.

Second, the advocacy-related mission and work seem to have a paradoxical effect on internal conduct. On the one hand they are driving force, yet on the other hand their legitimacy may enable trade-offs in favor of primary advocacy work. This is understandable, given a NGO's advocacy role; however, the public-at-large may actually expect NGOs to also 'walk the talk' internally. These trade-offs represent ethical dilemmas faced by managers in these NGOs between processes (ethical internal operations) and consequences (advocacy mission accomplishment). We outline conflicting demands that NGOs face between advocacy work and a symbolic function as (internal and external) role model. We find that organizations respond to those demands in heterogeneous ways, even within the same NGO.

Third, while exploring these themes, this study extends the extant knowledge base on NGOs, which are organizations with missions beyond profit maximization. Our case findings show that their advocacy mission has both normative (perceived need to 'walk the talk'), cultural-cognitive (taken for granted), and legitimating effects on the NGOs' internal conduct.

This study had some limitations, such as the fact that it involved a limited number of advocacy NGOs and a limited geographical scope. Furthermore, the study focuses on institutional influences rather than organizational drivers and barriers to sustainable conduct. Future research could further explore the factors identified in this study, including the influence of a sustainable-related mission, perceived vulnerability, and immunity. In addition, organizational characteristics were found to potentially be among the important barriers in the adoption of sustainable conduct (next to institutional drivers and barriers), like organizational size, rented or old office buildings, a limited number of employees, and the internal global governance model (see also Bowen et al. 2001; Gallo and Christensen 2011; Min and Galle 2001). Future research could incorporate 
these characteristics. Another direction for future research would be a further analysis of organizations' position toward their role-model function in relation to organizations' identity (Greenwood et al. 2011; Kodeih and Greenwood 2013).

Finally, our research touches on a hidden form of institutional complexity: the way to cope with a symbolic role-model function. Advocates, consultants, or other organizations that tell (or advise) others what to do need to balance their main activities with this role-model function. A direct managerial implication of this study for those organizations is to appreciate that internal conduct has symbolic value and is more than just the infrastructure for fulfilling its mission. For the NGOs in this study, this would imply that organizational members should reflect on the position of their sustainable internal conduct and the rationale behind its current decentralized approach. A more centralized policy could set out principles for internal conduct across the organization.

\section{Compliance with Ethical Standards}

Conflict of interest The authors declare that they have no conflict of interest (see also the comments to the editorial office).

Open Access This article is distributed under the terms of the Creative Commons Attribution 4.0 International License (http://crea tivecommons.org/licenses/by/4.0/), which permits unrestricted use, distribution, and reproduction in any medium, provided you give appropriate credit to the original author(s) and the source, provide a link to the Creative Commons license, and indicate if changes were made.

\section{Appendix 1: Coding Structure}

\begin{tabular}{|c|c|c|}
\hline \multicolumn{3}{|l|}{ Initial codes } \\
\hline Subject & Codes & Remarks \\
\hline $\begin{array}{l}\text { Three institutional } \\
\text { pillars as described by } \\
\text { Scott (2008), where } \\
\text { those pillars are } \\
\text { outlined cognitive }\end{array}$ & $\begin{array}{l}\text { 1. Regulative } \\
\text { 2. Normative } \\
\text { 3. Cultural }\end{array}$ & $\begin{array}{l}\text { Both before coding and } \\
\text { during the coding } \\
\text { process, coders made } \\
\text { sense of the meaning } \\
\text { of the three pillars. } \\
\text { The regulative pillar, } \\
\text { with as basis of order } \\
\text { 'regulative rules' and } \\
\text { basis of legitimacy } \\
\text { 'legal sanctions' was } \\
\text { clearest. Regulative } \\
\text { influences, however, } \\
\text { turned out to be } \\
\text { minimal for NGOs } \\
\text { internal conduct. The } \\
\text { normative and } \\
\text { cultural-cognitive } \\
\text { were discussed more } \\
\text { often (see research } \\
\text { methods) }\end{array}$ \\
\hline
\end{tabular}

Initial codes

Subject

Character of the

influence on internal

sustainability; drivers

or barriers
4. Driver to practice
5. Driver to report
6. Barrier to practice
7. Barrier to report $\begin{array}{ll}\begin{array}{l}\text { Examples and outlines } \\ \text { of sustainability }\end{array} & \begin{array}{l}\text { 8. Practices } \\ \text { practices }\end{array} \\ \text { 9. Reporting } \\ \text { 10. Policies }\end{array}$

Organizational factors
Size, resources, knowledge/skills, governance issues, stage of development, mission

Governance
Remarks

Driver: positive, driving influence

Barrier: negative, slowing (or even blocking) influence

Distinction made in driver/barrier coding between practice and reporting as additional refinement.

Accountability and transparency are integral part of sustainable conduct, and in the final version/analysis, both sustainable practices and reporting are clustered as sustainable conduct. We used the refinement in the results and the discussion section where we mentioned reporting explicitly as nuances

Practices: descriptions of sustainable conduct as practiced in the organization

Reporting: descriptions of sustainability reporting as practiced in the organization

Policies: sections that referred to documents, rules, or guidelines that were guiding sustainable conduct

Next to institutional, legitimacy-related influences, also practical factors turned out to be influential factors. The size of the organization state of buildings, etc. owned or rented, specialist knowledge that was available due to advocacy work, and interactions between offices of the same NGO. We included those in our coding

The way the organization is governed (formal and informal) 


\section{Appendix 2: Code Relations Matrix}

Example of two excerpts of the code relation browser.

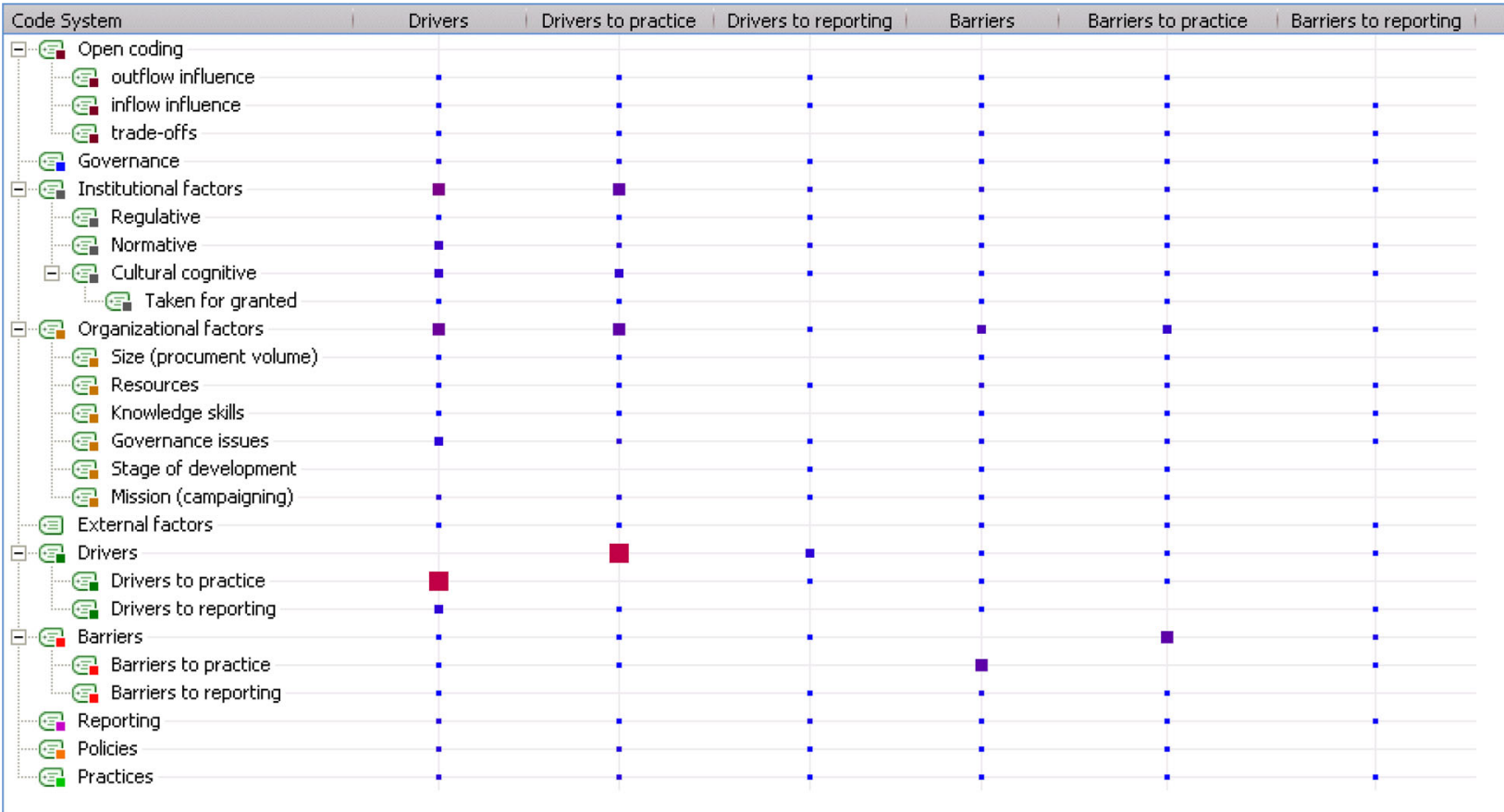

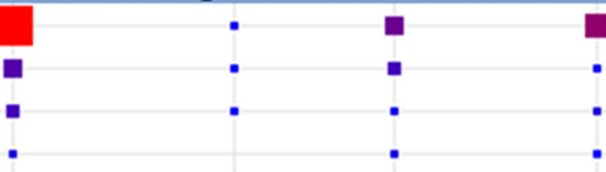

\section{References}

Aguinis, H., \& Glavas, A. (2012). What we know and don't know about corporate social responsibility: A review and research agenda. Journal of Management, 38(4), 932-968.

Ambec, S., \& Lanoie, P. (2008). Does it pay to be green? A systematic overview. Academy of Management Perspectives, 22(4), 45-62.

Anheier, H. K., \& Themudo, N. (2005). Governance and management of international membership organizations. Brown Journal of World Affairs, 11(2), 185-198.

Bansal, P. (2005). Evolving sustainably: A longitudinal study of corporate sustainable development. Strategic Management Journal, 26(3), 197-218.

Bansal, P., \& Corley, K. (2011). The coming of age for qualitative research: Embracing the diversity of qualitative methods. Academy of Management Journal, 54(2), 233-237.

Bansal, P., \& Roth, K. (2000). Why companies go green: A model of ecological responsiveness. The Academy of Management Journal, 43(4), 717-736.

Barratt, M., Choi, T. Y., \& Li, M. (2011). Qualitative case studies in operations management: Trends, research outcomes, and future research implications. Journal of Operations Management, 29(4), 329-342.
Bartkus, B., \& Glassman, M. (2008). Do firms practice what they preach? The relationship between mission statements and stakeholder management. Journal of Business Ethics, 83(2), 207-216.

Beu, D. S., Buckley, M. R., \& Harvey, M. G. (2003). Ethical decision-making: a multidimensional construct. Business Ethics: A European Review, 12(1), 88-107.

Blair-Loy, M., Wharton, A. S., \& Goodstein, J. (2011). Exploring the relationship between mission statements and work-life practices in organizations. Organization Studies, 32(3), 427-450.

Bowen, F. E., Cousins, P. D., Lamming, R. C., \& Faruk, A. C. (2001). The role of supply management capabilities in green supply. Production and Operations Management, 10(2), 174-189.

Campbell, J. L. (2007). Why would corporations behave in socially responsible ways? An institutional theory of corporate social responsibility. Academy of management. The Academy of Management Review, 32(3), 946-967.

Delgado-Ceballos, J., Aragón-Correa, J. A., Ortiz-de-Mandojana, N., \& Rueda-Manzanares, A. (2012). The effect of internal barriers on the connection between stakeholder integration and proactive environmental strategies. Journal of Business Ethics, 107(3), 281-293.

Dhanani, A., \& Connolly, C. (2015). Non-governmental organizational accountability: Talking the talk and walking the walk? Journal of Business Ethics, 129(3), 613-637. 
DiMaggio, P. J., \& Powell, W. W. (1983). The iron cage revisited: Institutional isomorphism and collective rationality in organizational fields. American Sociological Review, 48(2), 147-160.

Doh, J. P., \& Guay, T. R. (2004). Globalization and corporate social responsibility: How non-governmental organizations influence labor and environmental codes of conduct. Management International Review, 44(2), 7-29.

Doh, J. P., \& Guay, T. R. (2006). Corporate social responsibility, public policy, and NGO activism in Europe and the United States: An institutional-stakeholder perspective. Journal of Management Studies, 43(1), 47-73.

Domeisen, N., \& Hulm, P. (2006). Collaborating with an advocacy NGO. International Trade Forum, 2, 8.

Doz, Y. (2011). Qualitative research for international business. Journal of International Business Studies, 42(5), 582-590.

Drori, I., \& Honig, B. (2013). A Process model of internal and external legitimacy. Organization Studies, 34(3), 345-376.

Ebrahim, A. (2005). Accountability myopia: Losing sight of organizational learning. Nonprofit and Voluntary Sector Quarterly, 34(1), 56.

E.C. (2011). Attitudes of European citizens towards the environment (Vol. 2013)

Edelman. (2016). 2016 Edelman Trust Barometer Edelman.

Edelman. (2017). 2017 Edelman Trust Barometer Edelman.

Eisenhardt, K. M. (1989). Building theories from case study research. The Academy of Management Review, 14(4), 532-550.

Elkington, J. (1998). Cannibals with forks: The triple bottom line of 21st century business. Gabriola Island, BC: New Society Publishers.

Fassin, Y. (2009). Inconsistencies in activists' behaviours and the ethics of NGOs. Journal of Business Ethics, 90(4), 503.

Frink, D. D., \& Klimoski, R. J. (1998). Toward a theory of accountability in organizations and human resources management. Research in personnel and human resources management : a research annual, 16, 1-52.

Gallo, P. J., \& Christensen, L. J. (2011). Firm size matters: An empirical investigation of organizational size and ownership on sustainability-related behaviors. Business and Society, 50(2), 315-349.

Geels, F. W. (2004). From sectoral systems of innovation to sociotechnical systems. Research Policy, 33(6), 897-920.

Glover, J. L., Champion, D., Daniels, K. J., \& Dainty, A. J. D. (2014). An institutional theory perspective on sustainable practices across the dairy supply chain. International Journal of Production Economics, 152, 102-111.

Greenwood, R., Raynard, M., Kodeih, F., Micelotta, E. R., \& Lounsbury, M. (2011). Institutional complexity and organizational responses. The Academy of Management Annals, 5(1), 317-371.

Haack, P., Schoeneborn, D., \& Wickert, C. (2012). Talking the talk, moral entrapment, creeping commitment? Exploring narrative dynamics in corporate responsibility standardization. Organization Studies, 33(5-6), 815-845.

Handy, C. B. (1990). Understanding voluntary organizations: How to make them function effectively. London: Penguin.

Hoejmose, S. U., \& Adrien-Kirby, A. J. (2012). Socially and environmentally responsible procurement: A literature review and future research agenda of a managerial issue in the $21 \mathrm{st}$ century. Journal of Purchasing and Supply Management, 18(4), 232-242.

Hopkins, M. S., Kruschwitz, N., Haanaes, K., Kong, M. T., Arthur, D., \& Reeves, M. (2011). Sustainability: The 'embracers' seize advantage. MIT Sloan Management Review, 52(3), 3-27.

Jepson, P. (2005). Governance and accountability of environmental NGOs. Environmental Science \& Policy, 8(5), 515-524.
Kiron, D., Kruschwitz, N., Haanaes, K., \& Velken, I. V. S. (2012). Sustainability nears a tipping point. MIT Sloan Management Review, 53(2), 69-74.

Kleindorfer, P. R., Singhal, K., \& van Wassenhove, L. N. (2005). Sustainable operations management. Production and Operations Management, 14(4), 482-492.

Kodeih, F., \& Greenwood, R. (2013). Responding to institutional complexity: The role of identity. Organization Studies, 5(1), 317-371.

Kong, N., Salzmann, O., Steger, U., \& Ionescu-Somers, A. (2002). moving business/industry towards sustainable consumption: The role of NGOs. European Management Journal, 20(2), 109-127.

Kostova, T., \& Roth, K. (2002). Adoption of an organizational practice by subsidiaries of multinational corporations: Institutional and relational effects. The Academy of Management Journal, 45(1), 215-233.

Kostova, T., \& Zaheer, S. (1999). Organizational legitimacy under conditions of complexity: The case of the multinational enterprise. The Academy of Management Review, 24(1), 64-81.

Kourula, A., \& Laasonen, S. (2010). Nongovernmental organizations in business and society, management, and international business research review and implications from 1998 to 2007. Business and Society, 49(1), 35-67.

Kraatz, M., \& Block, E. (2008). Organizational implications of institutional pluralism. In R. Greenwood, C. Oliver, \& R. Suddaby (Eds.), The SAGE handbook of organizational institutionalism (pp. 243-275). London: SAGE Publications Ltd.

Le Menestrel, M., \& de Bettignies, H.-C. (2002). Processes and consequences in business ethical dilemmas: The oil industry and climate change. Journal of Business Ethics, 41(3), 251-266.

Low, W., \& Davenport, E. (2009). Organizational leadership, ethics and the challenges of marketing fair and ethical trade. Journal of Business Ethics, 86, 97-108.

Lu, J. W., \& Xu, D. (2006). Growth and survival of international joint ventures: An external-internal legitimacy perspective. Journal of Management, 32(3), 426-448.

Matten, D., \& Moon, J. (2008). "Implicit" and "explicit" CSR: A conceptual framework for a comparative understanding of corporate social responsibility. Academy of Management Review, 33(2), 404-424.

Meyer, J. W., \& Rowan, B. (1977). Institutionalized organizations: Formal structure as myth and ceremony. The American Journal of Sociology, 83(2), 340-363.

Miles, M. B., \& Huberman, A. M. (1994). Qualitative data analysis: An expanded sourcebook. Thousand Oaks, CA: Sage Publications.

Min, H., \& Galle, W. P. (2001). Green purchasing practices of US firms. International Journal of Operations \& Production Management, 21(9/10), 1222-1238.

O'Fallon, M. J., \& Butterfield, K. D. (2005). A review of the empirical ethical decision-making literature: 1996-2003. Journal of Business Ethics, 59(4), 375-413.

O'Dwyer, B., \& Unerman, J. (2008). The paradox of greater NGO accountability: A case study of Amnesty Ireland. Accounting, Organizations and Society, 33(7-8), 801-824.

Orr, R. J., \& Scott, W. R. (2008). Institutional exceptions on global projects: A process model. Journal of International Business Studies, 39(4), 562-588.

Ossewaarde, R., Nijhof, A., \& Heyse, L. (2008). Dynamics of NGO legitimacy: How organising betrays core missions of INGOs. Public Administration and Development, 28(1), 42-53.

Pache, A.-C., \& Santos, F. (2010). When worlds collide: The internal dynamics of organizational responses to conflicting institutional demands. Academy of Management Review, 35(3), 455-476. 
Pagell, M., \& Shevchenko, A. (2014). Why research in sustainable supply chain management should have no future. Journal of Supply Chain Management, 50(1), 44-55.

Podsakoff, P. M., MacKenzie, S. B., Lee, J.-Y., \& Podsakoff, N. P. (2003). Common method biases in behavioral research: A critical review of the literature and recommended remedies. Journal of Applied Psychology, 88(5), 879-903.

Roome, N. (2011). Looking back, thinking forward: Distinguishing between weak and strong sustainability. In P. Bansal \& A. Hoffman (Eds.), The Oxford handbook of business and the natural environment (pp. 620-629). Oxford: Oxford Press.

Scott, W. R. (2008). Institutions and organizations: Ideas and interests. Los Angeles: Sage Publications.

Simaens, A., \& Koster, M. (2013). Reporting on sustainable operations by third sector organizations. Public Management Review, 15(7), 1040-1062.

Singh, J. V., Tucker, D. J., \& House, R. J. (1986). Organizational legitimacy and the liability of newness. Administrative Science Quarterly, 31(2), 171-193.

Steffek, J., \& Hahn, K. (2010). Introduction: Transnational NGOs and Legitimacy, Accountability, Representations. In J. Steffek \& K. Hahn (Eds.), Evaluating transnational NGOs: Legitimacy, accountability, representation (pp. 1-25). New York: Palgrave Macmillan.

Suchman, M. C. (1995). Managing legitimacy: Strategic and institutional approaches. The Academy of Management Review, 20(3), 571-610.

Teegen, H., Doh, J. P., \& Vachani, S. (2004). The importance of non governmental organizations (NGOs) in global governance and value creation: An international business research agenda. Journal of International Business Studies, 35(6), 463-483.

Trevino, L. J., Thomas, D. E., \& Cullen, J. (2008). The three pillars of institutional theory and FDI in Latin America: An institutionalization process. International Business Review, 17(1), $118-133$.
UIA, U. o. I. A. (2011). Yearbook of international organizations 2011-2012. In U. o. I. Associations (Ed.), Guide to global civil society networks (48 ed.). Leiden: Brill.

Unerman, J., \& O’Dwyer, B. (2006a). On James Bond and the importance of NGO accountability. Accounting, Auditing \& Accountability Journal, 19(3), 305-318.

Unerman, J., \& O'Dwyer, B. (2006b). Theorising accountability for NGO advocacy. Accounting, Auditing \& Accountability Journal, 19(3), 349-376.

Unerman, J., \& O’Dwyer, B. (2010). Ngo accountability and sustainability issues in the changing global environment. Public Management Review, 12(4), 475-486.

Valente, M. (2012). Theorizing firm adoption of sustaincentrism. Organization Studies, 33(4), 563-591.

Van Cranenburgh, K. C., Liket, K., \& Roome, N. (2013). Management responses to social activism in an era of corporate responsibility: A case study. Journal of Business Ethics, 118(3), 497-513.

Vermeulen, P. A. M., Zietsma, C., Greenwood, R., \& Langley, A. (2016). Strategic responses to institutional complexity. Strategic Organization, 14(4), 277-286.

Waddock, S. (2008). Building a new institutional infrastructure for corporate responsibility. The Academy of Management Perspectives, 22(3), 87-108.

Walker, H., Di Sisto, L., \& McBain, D. (2008). Drivers and barriers to environmental supply chain management practices: Lessons from the public and private sectors. Journal of Purchasing and Supply Management, 14(1), 69-85.

Wiser, R. H., Fowlie, M., \& Holt, E. A. (2001). Public goods and private interests: Understanding non-residential demand for green power. Energy Policy, 29(13), 1085-1097.

Yin, R. K. (2009). Case study research: Design and methods. Thousand Oaks, CA: Sage Publications. 